\title{
Students' Perception of English as a Medium of Instruction (EMI) in English Classroom
}

\author{
Denni Rahmadani \\ denni22ej@gmail.com \\ State Islamic Institute of Palangka Raya \\ Jl. G. Obos Komplek Islamic Centre Palangka Raya, Kalimantan Tengah, Indonesia
}

Received: July 12, 2016; Accepted: September 12, 2016; Published: September 27, 2016

\begin{abstract}
This study aims to uncover what extent of the students' expectation of English as a medium of instruction (EMI) used by the English teacher in teaching English at senior high schools in Palangka Raya, Indonesia. A survey research method was applied. The survey was conducted at the four schools: MAN Model, MA Muslimat NU, SMAN 4, and SMKN 2 in Palangka Raya. To collect the data, the study employs the questionnaire with 10 items given to 134 students of the second grade taken from one class of each of the schools. It was used the cluster random sampling technique to take the samples. The items were designed for evaluating the factual, behavioral, and attitudinal condition of EMI in the English classroom. As a result of the study, it is shown that most of the students agree of EMI dominantly applied by the English teacher in the teaching of English subject. By implementing EMI in this classroom, it can increase students' English ability with appropriate English standard, motivate them to learn English, improve their confidence to speak English, help them to comprehend English textbook or article, and assist them to understand the international culture.
\end{abstract}

Keywords: English as medium of instruction (EMI), English teaching, factual condition, behavioral condition, attitudinal condition

How to cite this paper: Rahmadani, D. (2016). Students' Perception of English as a Medium of Instruction (EMI) in English Classroom. Journal on English as a Foreign Language, 6(2), 131-144. 
English as a medium of instruction (EMI) can be defined as the use of the English language to teach academic subjects in countries or jurisdictions and implemented in some countries where the first language of the majority of the population is not English. Using English as the medium of instruction as the target language in the classroom is very important to do so for the process of language learning. Dickson (1996) stated that the use of the target language in the classroom greatly increases the students' exposure to the target language. Using the target language in the classroom, students are receiving more comprehensible input thus leading to more complex language structures. By using the target language in the classroom can provide a source of modeling for the students both in regards to the production of the language and the attitude toward the language.

Additionally, Dearden (2013) stated that there appears to be a fastmoving worldwide shift, in non-anglophone countries, from English being taught as a foreign language (EFL) to English being the medium of instruction (EMI) for academic subjects. EMI is also increasingly being used in universities, secondary schools and even primary schools. The EMI phenomenon it is highly unlikely that the majority of countries, certainly in the tertiary phase, will seek to reverse the decision to push forward with even more courses taught in English which. If the phenomenon cannot be slowed down to a speed that will allow reflection, then at the very least it is incumbent on researchers and teachers alike to strive to make the experience for their learners as enabling and as rewarding as possible.

Although using English as a medium of instruction or as the target language by the English teacher can cause some stress, but it is very important to do so for the process of language learning. According to Dickson (1996), the importance of using the target language in the classroom are: first, the use of the target language in the classroom greatly increases the students' exposure to the target language. This is very important, especially in foreign language classrooms where the target language is not heard outside of the classroom context. The goal is to make the context as close to a second language context (where the target language would be heard outside of the classroom) as possible in order to give students maximum exposure to the language. Second, by using the target language in the classroom, students are receiving more comprehensible input thus leading to more complex language structures. By using the target language, students are not only learning 'about' the language but also learning 'through' the language. Certain classroom commands or common expressions can be acquired through routine use. Last, using the target language in the classroom can provide a source of modeling for the students both in regards to the production of the language and the attitude toward the 
language. If the teacher is able to show proper use of the language daily, students can use that teacher as an example or model for production. In addition, if the teacher treats the language as more than just a subject for study but shows the value of the language by using it, students will be more likely to gain a better appreciation for the language.

English Medium Instruction students and teachers will learn is not 'about' English (as a subject) but 'through' English (as a medium). Ibrahim (2014) stated an English as a medium, English is likely to be used to perform academic tasks involving various classroom-related communicative activities like gaining information (listening \& reading) and conveying information (speaking \& writing). In the fact of the field that EMI will allow students and teachers to read in English (textbooks) more extensively can contribute to the success of acquiring the language. EMI which offers students and teachers more opportunities to speak English (e.g. in lectures, comments, discussions, presentations, interactions, tests, etc.) means that it is a source of comprehensible output, another component responsible for second language acquisition.

English education in some countries is limited as situate English language as the subject which all students in certain level are compulsory to take it. For instance almost Asian countries, the English language has not been thought in primary school where the rest just started at the secondary level. Nevertheless, some countries regulate the English language as a medium of teaching and compulsory right from primary school. The use of English language as a medium of instruction is a policy that implemented in some countries where there is a tradition of using English in daily life or otherwise.

English in Indonesia is only a foreign language, not a second language. According to Dearden (2013), until the year 2003 international EMI schools operating in Indonesia were restricted to the children of expatriates. EMI was used for core subjects such as science and math. Education Law Number 20 of 2003, article 50, relaxed these restrictions and required that the central or regional governments establish one 'International Standard School' (ISS) at all levels, primary, junior, secondary and senior secondary. This government sponsored program was implemented in 2006 in a special stream of public schools, the Rintisan Sekolah Bertaraf Internasional or RSBI/SBI (International Standard Schools).

In addition, Idris (2014) states that English is only a special foreign language usually taught as a subject in schools. The fact that the Indonesian language is also an important language (not just a vernacular) dominating important functions such as political, economic, academic, social, etc. In 
Indonesian society, it can certainly impose a barrier towards efforts in acquiring the English language.

Academically, teachers and students low proficiency may lead to inefficient and ineffective teaching and learning processes. Most of the teachers have relatively limited proficiency in English. As Ibrahim (2014) said that teacher who cannot speak English fluently and accurately will probably be rendered incompetent to perform one of their chief traditional roles, teaching. Pauses, hesitancies, circumlocutions, wordiness, and grammatical, lexical, and pronunciation inaccuracies may characterize much of their explanation, and this will certainly slow down or even hamper their students' grasp of the content of instruction. In addition, a teacher who has a poor reading comprehension of English textbooks, an essential source of information for them, may cause them a lack of understanding or even a misunderstanding, which in turn may result in misinformation, an effect damaging to students' academic development.

In any other problem, it is happening at several senior high schools in Palangka Raya. Based on the observation of some students and teachers, and self' experiences teaching in one of the senior high schools in Palangka Raya, it is found that Bahasa Indonesia is still used in the reality of medium instruction in the English class. The usage of Bahasa Indonesia is used to compensate English. However, although mixed-mode teaching or code-switching in the classroom sometimes helps to make teaching and learning processes becoming more efficient, it should not be used to serve as a transition to a full EMI program. It may inhibit the process of acquiring English and undermine the very existence of an EMI program.

From the explanation above, this study aims to find the answer to what actually the students expect from their English teachers especially in the form of the English use in the classroom. Therefore, this research sought to uncover to what extent of the "students' perception of English as a medium of instruction in teaching English at senior high schools in Palangka Raya".

This study aims to uncover the students' perception of EMI in the classroom at Senior High School level. Feldman (2011) stated perception is the process by which organisms interpret and organize sensation to produce a meaningful experience of the world. Sensation usually refers to immediate, relativity unprocessed result of stimulation of sensory receptors in the eyes, ears, nose, tongue, or skin. On the other hand, perception is the sorting out, interpretation, analysis, and integration of stimuli carried out by the sense organs and brain. Every people have a different perception on the same thing. It is because of the factors of the people knowing of the world and his feeling of that. 
To be more specific this study limited the student's perception to some criteria. Nobel (2006) stated the concept of students perception; First, Students' perceptions of themselves influence the amount of effort they are willing to put forth in school, their educational aspirations, and their academic achievement. Research has shown that positive attitudes towards self and school ultimately determine students' motivation and effort in doing schoolwork (self-concept).

Second, the concept of causal attribution states that students tend to seek a cause for their successes and failures. Students who attribute their success and failures to positive attributions (success is due to high ability, whereas failure is due to a lack of effort) tend to perform better than do their negatively-oriented counterparts. Negatively-oriented students are those students who attribute their success to luck, and they attribute their failure to low ability or to external sources (positive attribution).

Third, Self-regulated learners are typically described as active learners who effectively manage the cognitive, motivational, and behavioral aspects of their learning. Academic self-regulation includes a strong sense of self-efficacy, which refers to a student's resilience, their ability to rebound or bounce back from adversity (self-efficacy).

Fourth, coping strategies (e.g., problem-solving skills, interpersonal communication skills) protect to environmental stress. Students who indicated that they knew specific behaviors that result in successful outcomes, and that they felt able to execute these behaviors, achieved better grades than students without these strategies. Students who are academically at risk have lower selfperceptions of their interpersonal communication skills than do students who are not academically at-risk (problem-solving skills and interpersonal communicating skill).

Fifth, consistent with other studies on family background and achievement, students from lower income, less educated families are less likely to succeed academically in high school. This finding is most often attributed to differences among groups in their opportunities to learn, the quality of the education to which they have access, and to their home environment (family background).

It is expected that this study is to give information as a consideration of a base of policy making in the reality of education at senior high schools in Palangka Raya. Moreover, it gives the contributions for the English teachers at Senior High Schools in Palangka Raya by measuring the students' response of English as a medium of instruction in teaching English; hopefully, the English teachers develop their ways to teach a good variety of things to this type of situation in the future. 
In concern with the research investigating EMI, Aritonang (2014) did a research on motivation and confidence of Indonesian teachers to use English as a medium of instruction. The finding revealed a varying increase in the levels of motivation and confidence of the participants and transformation of extrinsic to intrinsic motivation appeared to occur. The last result is some factors give a contribution to increasing the motivation and confidence.

Thirunavukkarsu (2013) said that the main aspect of the way in which English is used as a medium of instruction is that in government schools some subjects are taught in English while some other subjects are taught in Tamil. This helps the students be balanced bilinguals because they constantly learn their first language while acquiring mastery in L2. Eventually, it is assumed that this will facilitate the additive bilingualism and children would be balanced bilinguals.

Sultan, Borland, and Eckersley (2012) reported English medium of instruction in Indonesian public junior secondary school. First, most of the students of EMI improved their English because they have extra time to develop their skills outside the schools. Second, the data indicated that EMI students use English more often than their counterpart in no-EMI programs both at home and at schools. Together with that, students in urban areas speak more in the mix between English and Indonesia than students in rural areas. Third, most of the students responded that they learn English based on instrumental orientation. It is clear to make dissidence.

\section{METHOD}

This research was descriptive quantitative which the approach is a survey research. Toendan (2013) stated the descriptive research is a research that involving the collection of the data for the purpose of describing existing conditions. Also, Creswell (2012) stated that in one line, the survey is a procedure used by the researcher to describe the attitudes, opinions, behaviors, or characteristics of the population. This survey used cluster random sampling technique to establish the sample. Additionally, Toendan (2013) stated cluster random sampling is used when it is more feasible or convenient to select groups of individual that it is to select individuals from a defined population. To establish the sample this study used some step, first, chosen the major subgroup for $10 \%$ out of the total of population 40 senior high school; $40: 10 \%=$ 4 schools. The second step, select randomly of one minor subgroup (class) on the second grade from within each those schools in total there are 4 classes, namely; XI-Bahasa of MAN Model Palangka Raya, XI-IPA of MA Muslimat N.U Palangka Raya, XI-Bahasa /10 of SMA Negeri 4 Palangka Raya, and XI-APK / 
01 of SMK Negeri 2 Palangka Raya. The final step includes all students from each of those classes in totally 134 students (Figure 1).

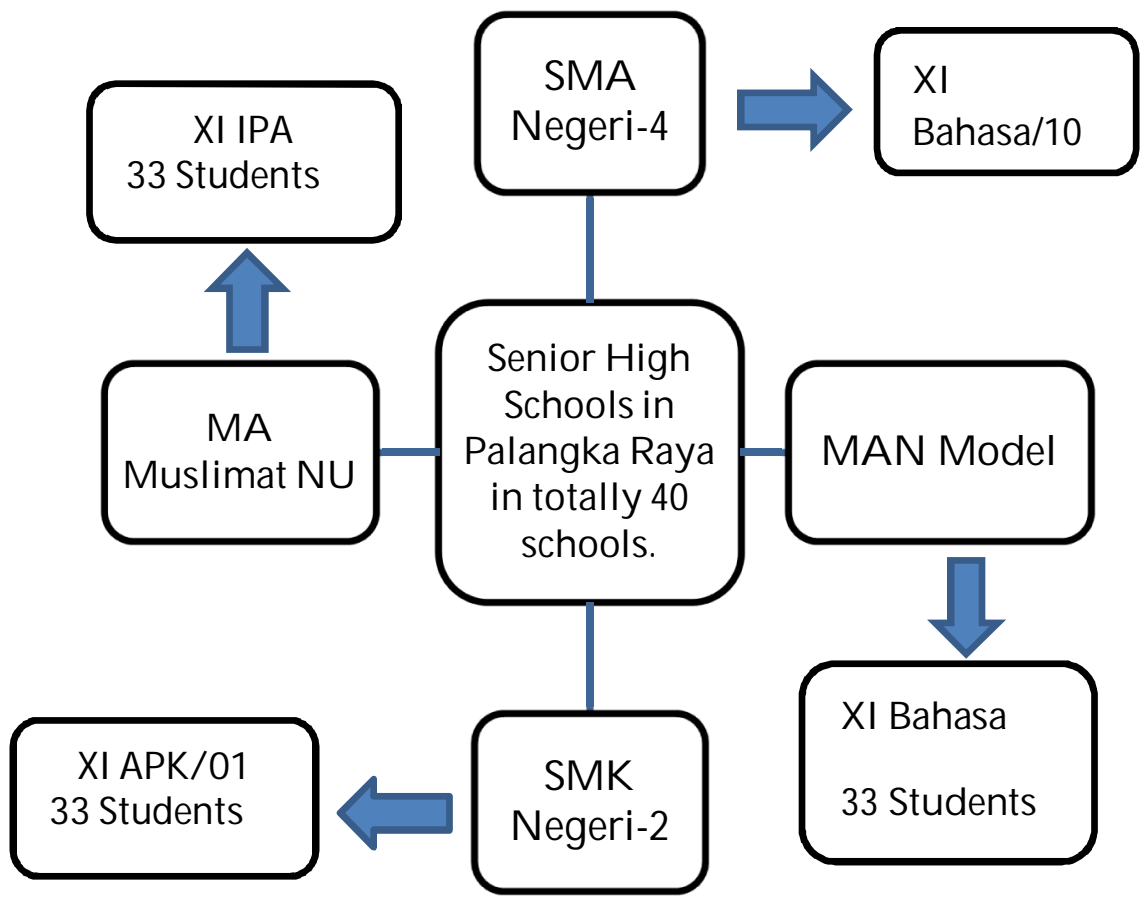

Figure 1. The Established Sample Based on Cluster Random Sampling Technique

This survey research used questionnaire only as the main instrument. The samples of the population are taken from the major subgroup (Table 1). Mckey (2008) stated that survey is specifically thought as written questionnaire and it is clearly different with the interview. Meanwhile, Hornby (2003) stated that questionnaire is a written or printed list of questions to be answered by a number of people especially as part of a survey.

Table 1. The Highlight of Major Subgroup

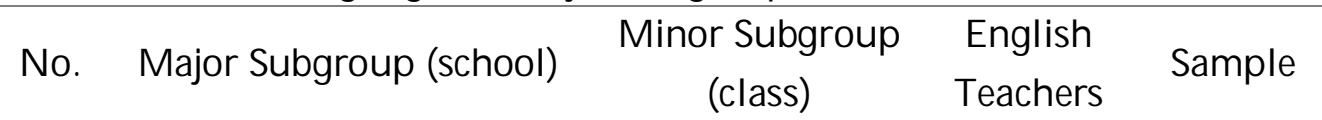

\begin{tabular}{|c|c|c|c|c|}
\hline 1 & MAN Model & XI Bahasa & 4 & 33 \\
\hline 2 & MA Muslimat NU & XI IPA & 2 & 36 \\
\hline 3 & SMA Negeri- 4 & XI Bahasa/10 & 4 & 32 \\
\hline 4 & SMK Negeri- 2 & XI APK 01 & 5 & 33 \\
\hline & & & 15 & 134 \\
\hline
\end{tabular}

Journal on English as a Foreign Language, 6(2), 131-144

Copyright (C) 2016 by JEFL, p-ISSN 2088-1657; e-ISSN 2502-6615 
Related to the questionnaire, Dornyei cited by Nirwanto (2013) points out that the questionnaires can yield three types of data about the respondent: Factual, behavioral, and attitudinal. Factual questions (also called "classification" questions or "subject descriptors") are used to find out about who the respondents are. They typically cover demographic characteristics (e.g., age, gender, and race), residential location, marital and socioeconomic status, the level of education, religion, occupation as well as any other background information that may be relevant to interpreting the findings of the survey.

Behavioral questions are used to find out what the respondents are doing or have done in the past. They typically ask about people's actions, lifestyles, habits, and personal history. Perhaps the most well-known questions of this type in L2 studies are the items in language learning strategy inventories that ask about the frequency of the use of a particular strategy in the past.

Attitudinal questions are used to find out what people think. This is a broad category that concerns attitudes, opinions, beliefs, interests, and values. These five interrelated terms are not always distinguished or defined very clearly in the literature. The term "Attitudes" concerns evaluative responses to a particular target (e.g., people, institution, and situation). The term "Opinions" is just as subjective as attitudes, but they are perceived as being more factually based and more changeable. People are always aware of their opinions but they may not be fully conscious of their attitudes. The term "Beliefs" has a stronger factual support than opinions and often concerns the question as to whether something is true, false, or right. The term "Interests" is a preference for particular activities. The term "Values" on the one hand, concerns preferences for "life goals" and "ways of life."

In this study, it was used the Likert scale as the kind of questionnaire. Cohen's (2010) a Likert scale provides a range of responses to a given question or statement. Ary, Jacobs, and Sorensen (2010) stated that a Likert scale shows a set of statements of the topic and asking the respondent to choose whether they strongly agree, agree, are undecided, disagree, strongly disagree. Then the writer also used Bahasa Indonesia in order to respondents more comfortable and get the point better of the questionnaire. Dornyei and Taguchi (2000) stated questionnaire research makes the inherent assumption that the respondents can read and write well. It is, therefore, understandable that for respondents with literacy problems or with limited L2 proficiency.

It was tried out the test instrument before it applied to the real sample in the research. The writer gave a test of try out to second-grade students at SMANU Palangka Raya. To get the data of try out, it was used some procedures as follows. The writer made and prepare a test of try out, gave a test of try out to 
the students, asked the students to do a test of trying out, collected the student's answer, calculated and gave a score to the students' answer, then analyzed the obtain data to know the validity of the instrument, and instruments reliability.

According to Ary et al. (2010), validity is defined as the extent to which scores on a test enable one to make meaningful and appropriate interpretations. Meanwhile, Cohen (2000) stated in the questionnaire, to measure the validity is whether respondent who complete the questionnaire do so accurately, honestly and correctly and second whether those who fail to return their questionnaire would have given the same distribution of answer as did the returns. Face validity is taken to ensure that the questionnaire is valid. Face validity refers to the extent to which examinees believe the instrument is measuring what it is supposed to measure. Doing pilot study was not only to know the students' difficulties in answer the questionnaire but also measured the construct validity of the questionnaire.

Additionally, Ary et al. (2010) stated that reliability is the degree of consistency with which it measures whatever it is measuring. The reliability of a measuring instrument is the degree of consistency with which it measures whatever it is measuring. This quality is essential in any kinds of measurement. in order to assure the reliability of a survey, several measures can be used (McKay, 2008). It was using SPSS 20.0 program in finding the reliability. The degree of alpha's Cronbach Alpha is higher than $r$ table (0.632). The result of reliability above as follows:

To collect the data needed, questionnaires with open-ended questions was given to the participants. There were some step should be done, they are as follows; preparing the questionnaire, giving the questionnaire to the respondents, collecting the responses, calculating the result of responses, analyzing the data obtained using SPSS program version 20.0, finally concluding the students' perceptions of English as a medium of instruction in senior high schools in Palangka Raya.

There were three steps to analyze the data; they are item scores, the distribution of frequency and percentage, central tendency, calculating the mean using formula, median, and mode, interpreting the data result and giving the conclusion. Then coding the questionnaire result. McKay (2008) stated coding categories is the first thing to do for the writer when deciding compiling survey research. This research adopted the Fukuda's way to display the data results.

\section{FINDINGS}

The data presentation of the item score of the students' perception shown in the measurement of central tendency (mean, median, and mode), the 
measurement of deviation standard, the table of frequency distribution and the chart of the frequency distribution. The total of the respondents were 134 students and it consisted of 10 items of the questionnaire. The results of questionnaire are as follow (Table 2).

Item 1, English as a Medium of Instruction increases my standard of English and motivate me to learn English. There are 42 students (31.3\%) stated strongly agree, 88 students $(65.7 \%)$ agree, and 4 students (3.0\%) disagree.

Item 2, English as a Medium of Instruction helps me more capable of speaking English. There are 30 students $(22.4 \%)$ stated strongly agree, 80 students $(59.7 \%)$ agree, 22 students (16.4\%) disagree, and 1 student $(0.7 \%)$ strongly disagree.

Item 3, English as a Medium of Instruction helps me to understand easier about English textbook or article. There are 48 students (35.8\%) stated strongly agree, 69 students (51.5\%) agree, and 17 students (12.7\%) disagree.

Item 4, English as a Medium of Instruction facilitates me to understand international cultures. There are 40 students $(29.9 \%)$ stated strongly agree, 73 students $(54.5 \%)$ agree, and 21 students $(15.7 \%)$ disagree.

Item 5, it is easy to understand a teacher of English subject. There are 8 students (6.0\%) stated strongly agree, 63 students (47.0\%) agree, $62(46.3 \%)$ students stated disagree and 1 student $(0.7 \%)$ stated strongly disagree.

Item 6, I understand very well when the English teacher speaks English during the class going on. There are 4 students (3.0\%) state strongly agree, 55 students $(41.0 \%)$ agree, 69 students $(51.5 \%)$ disagree, 5 students $(3.7 \%)$ stated strongly disagree, and 1 student $(0.7 \%)$ who do not answer anything.

Item 7, English is applied as a Medium of Instruction in the English subject. There are 42 students (31.3\%) stated strongly agree, 63 students (47.0\%) state agree, 27 students (20.1\%) stated disagree, and 2 students (1.5\%) stated strongly disagree.

Item 8, the English teachers must use English when teaching English subject. There are 22 students (16.4\%) stated strongly agree, 55 students $(41.0 \%)$ agree, 52 students (38.8\%) disagree, and 5 students (3.7\%) strongly disagree.

Item 9, the Indonesian Language is applied as a Medium of Instruction in the teaching of English subject. There are 56 students (41.8\%) state strongly agree, 69 students $(51.5 \%)$ agree, and 6 students $(4.5 \%)$ disagree, 1 student $(0.7 \%)$ strongly disagree, and 2 students $(1.5 \%)$ who do not answer anything.

Item 10, the combination of English and Indonesian language in English subject is appropriate for the condition of students in each class of school. There are 88 students $(65.7 \%)$ stated strongly agree, 41 students (30.6\%) agree, and 5 students $(3.7 \%)$ disagree. 
Table 2. The Questionnaire Result (Percentage, Frequency, and Deviation Score)

\begin{tabular}{|c|c|c|c|c|c|c|c|c|c|c|c|}
\hline \multirow{2}{*}{$\begin{array}{l}\text { Ite } \\
\mathrm{m}\end{array}$} & \multirow{2}{*}{$\begin{array}{l}\text { Percent\& } \\
\text { Number }\end{array}$} & \multicolumn{5}{|c|}{ Scale } & \multirow{2}{*}{ Total } & \multirow{2}{*}{$\mathrm{MN}$} & \multirow{2}{*}{$\begin{array}{l}M \\
D\end{array}$} & \multirow{2}{*}{$\begin{array}{l}\mathrm{M} \\
\mathrm{O}\end{array}$} & \multirow{2}{*}{$\begin{array}{l}\text { St. } \\
\text { Dev }\end{array}$} \\
\hline & & $\mathrm{SA}=4$ & $A=3$ & $\mathrm{D}=2$ & $\mathrm{SD}=1$ & $M S=0$ & & & & & \\
\hline \multirow{2}{*}{1} & Percent: & 31.3 & 65.7 & 3.0 & 0 & 0 & $100 \%$ & 3.28 & 3 & 3 & 0.51 \\
\hline & Number: & 42 & 88 & 4 & - & - & 134 & & & & \\
\hline \multirow{2}{*}{2} & Percent: & 22.4 & 59.7 & 16.4 & 0.7 & 0 & $100 \%$ & 3.02 & 3 & 3 & 0.69 \\
\hline & Number: & 30 & 80 & 22 & 1 & - & 134 & & & & \\
\hline \multirow{2}{*}{3} & Percent: & 35.8 & 51.5 & 12.7 & 0 & 0 & $100 \%$ & 3.23 & 3 & 3 & 0.65 \\
\hline & Number: & 48 & 69 & 17 & - & - & 134 & & & & \\
\hline \multirow{2}{*}{4} & Percent: & 29.9 & 54.5 & 15.7 & 0 & 0 & $100 \%$ & 3.14 & 3 & 3 & 0.66 \\
\hline & Number: & 40 & 73 & 21 & - & - & 134 & & & & \\
\hline \multirow{2}{*}{5} & Percent: & 6.0 & 47.0 & 46.3 & 0.7 & 0 & $100 \%$ & 2.58 & 3 & 3 & 0.61 \\
\hline & Number: & 8 & 63 & 62 & 1 & - & 134 & & & & \\
\hline \multirow{2}{*}{6} & Percent: & 3.0 & 47.0 & 45.5 & 3.7 & 0,7 & $100 \%$ & 2.48 & 2 & 3 & 0.65 \\
\hline & Number: & 4 & 63 & 61 & 5 & 1 & 134 & & & & \\
\hline \multirow{2}{*}{7} & Percent: & 31.3 & 47.0 & 20.1 & 1.5 & 0 & $100 \%$ & 3.08 & 3 & 3 & 0.75 \\
\hline & Number: & 42 & 63 & 27 & 2 & - & 134 & & & & \\
\hline \multirow{2}{*}{8} & Percent: & 16.4 & 41.0 & 38.8 & 3.7 & 0 & $100 \%$ & 2.70 & 3 & 3 & 0.78 \\
\hline & Number: & 22 & 55 & 52 & 5 & - & 134 & & & & \\
\hline \multirow{2}{*}{9} & Percent: & 41.8 & 51.5 & 4.5 & 0.7 & 1,5 & $100 \%$ & 3.31 & 3 & 3 & 0.73 \\
\hline & Number: & 56 & 69 & 6 & 1 & 2 & 134 & & & & \\
\hline \multirow{2}{*}{10} & Percent: & 65.7 & 30.6 & 3.7 & 0 & 0 & $100 \%$ & 3.62 & 4 & 4 & 0.55 \\
\hline & Number: & 88 & 41 & 5 & - & - & 134 & & & & \\
\hline
\end{tabular}

From the data findings above, most of the students stated agree with all items. It could be seen by the data that frequently all items almost have mode 3 and the median also stated as same as the mode. For the mean, the data shown that the combined performance of the entire group was the highest value in item 10 (3.62) and the lowest value in item 6 (2.48). Meanwhile, standard deviation, the highest value was item $8(0.78)$ and the lowest value was item 1 (0.51). It means that the item 8 was more heterogeneous than item 1 .

\section{DISCUSSION}

The objective of the study in this research was to uncover the students' perception of English as a Medium of Instruction used by the English teachers in teaching English at senior high schools in Palangka Raya. Then the data result of the students' perception were described by the writer based on the research type that is descriptive quantitative research. This research is to uncover the "what" of students' perception of English as a medium of instruction used by the English teachers in teaching English, then the writer describing the data result of students' response of English as a Medium of 
instruction used by the English teachers in teaching English by descriptive research.

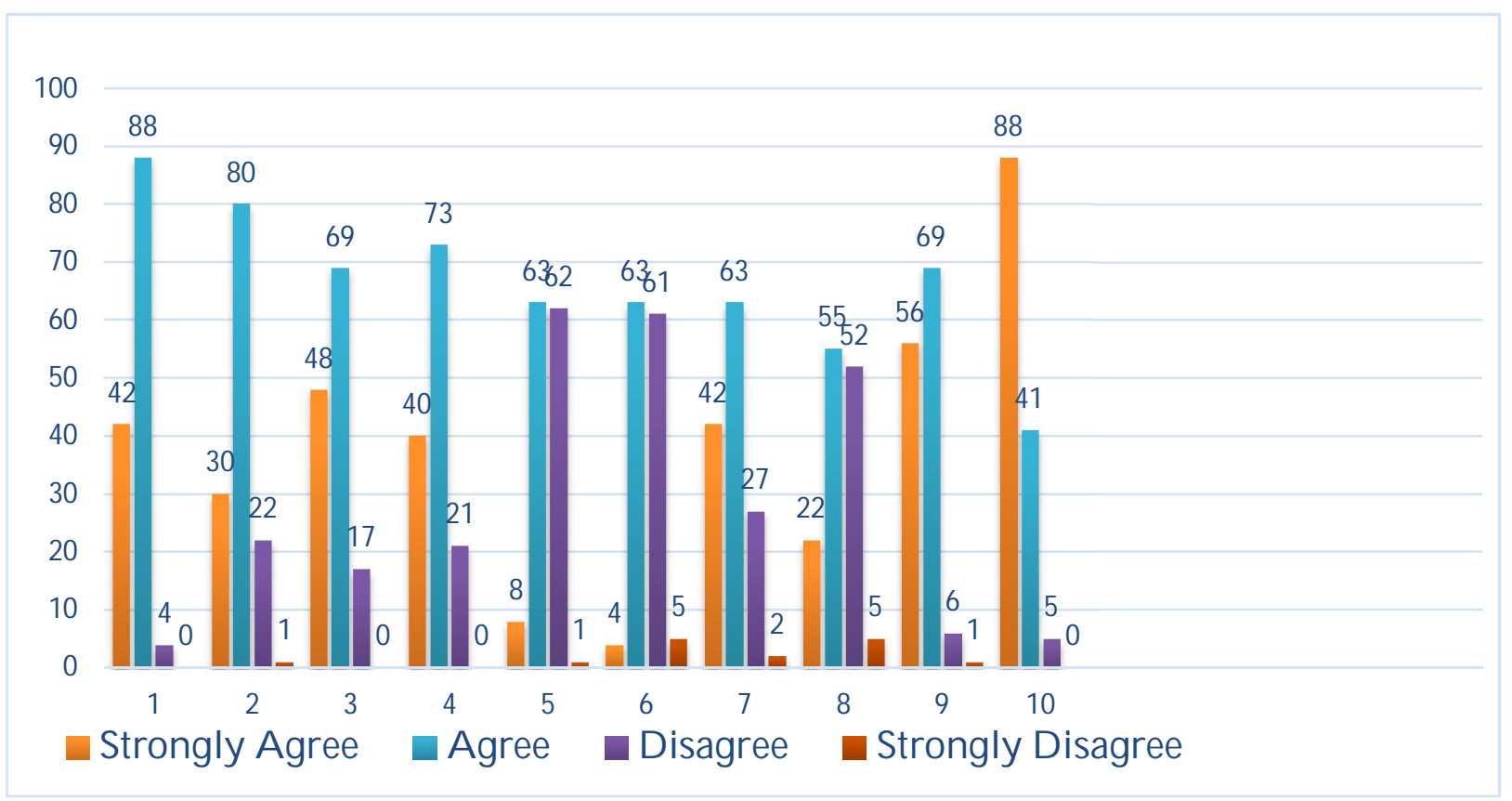

Figure 2. Chart of the Percentage and Frequency of Questionnaire

The discussion of the results' of this study as follows (Figure 2). In the items 1, 2, 3, and 4 it is shown that English as a medium of instruction gave them motivation and contribution of English. This result was supported by theory Sultan (2012) that the EMI students achieved a higher frequency of English language use both at home and at school, a more positive attitude toward English and higher motivation to learn English. Also, it is supported by Aritonang (2014), it was said that the participation in the blended learning course appeared to increase the level of motivation and confidence of teacher participants to learn and use English as a medium of instruction.

In the items 5 and 6, it is shown that the students' ability and behavior of English as a medium of instruction. Item 5, it is easy to understand a teacher of English subject. In the items 7, 8, 9, and 10 it is shown the students' attitude of English as a medium of instruction in their school. The result was supported by Tarhan (2014), it said that a positive correlation was found between perceptions of English and perceptions of English-medium instruction for each group. Results also showed that all groups perceive English positively as a foreign language, and support the teaching and learning of English. The result found that most students in this survey had a positive response of English as a medium of instruction. It could be seen from the percentage score of the data 
result that $50 \%$ or 67 students stated 'agree' and $25 \%$ or 34 students stated 'strongly agree'. The data description previously that the score of Mode showed 3 frequently appeared or in the chart figure 4.1 was green, and also the median stated the same as mode, namely 3 .

From the data describe and the discussion above, it can answer the question in the problem of the study that what is the students' perception of English as a medium of instruction in the teaching of English? The result found that most students in this survey had a positive response of English as a medium of instruction. It could be seen from the percentage score of the data result that 50\% (67 students 'agree') and 25\% (34 students 'strongly agree'). The data description previously that the score of Mode showed 3 frequently appeared or in Figure 1 (green), and also the median is stated the same as mode, namely 3.

\section{CONCLUSION}

This survey research took the second-grade students of the four senior high schools in Palangka Raya namely, MA Muslimat NU Palangka Raya, MAN Model Palangka Raya, SMA Negeri-4 Palangka Raya, and SMK Negeri-2 Palangka Raya. Based on the result of the research, most students had positive perception or agreed toward English as a medium of instruction that it could increase the students' standard of English and motivate them to learn English, improve their confidence to speak up, and helps them to understand more of English textbook or article and international culture. It could be seen from the percentage score of the data result that 50\% (67 students stated 'agree') and 25\% (34 students stated 'strongly agree'). Mode and median also show positive frequently stated the same value 3. This survey also proved that English as a medium of instruction (EMI) in the perspective of students motivate them to learn English more and to communicate with it.

\section{REFERENCES}

Aritonang, M. (2014). Motivation and confidence of Indonesian teachers to use English as a medium of instruction. TEFLIN Journal, 25(2).

Ary, D., Jacobs, L. C., \& Sorensen, C. (2010). Introduction to Research in Education (8th Ed.). New York: Wadsworth/Thomson Learning.

Cohen. (2010). Research Methods in Education: Fifth Edition, London: Routledge Falmer.

Creswell, J. W. (2012). Educational research: Planning, conducting and evaluating quantitative and qualitative research. Boston: Pearson Education Inc.

Dearden, J. (2013). English as a medium of instruction: A growing global phenomenon. Oxford: University of Oxford. 
Dickson, P. (1996). Using the target language: A view from the classroom. National Foundation for Educational Research.

Driscoll, D. L. (2010). Introduction to primary research: observations, surveys, and interviews, Library of Congress Cataloging in Publication Data, 2.

Feldman, R. S. (2011). Understanding psychology. McGraw Hill Companies.

Ibrahim, J. (2014). The implementation of EMI (English medium instruction) in Indonesian universities.

Idris, S. (2014). Language policy and the construction of national and ethnic identities in Indonesia. San Antonio: The University of Texas at San Antonio.

Mckey, S. L. (2008). Researching second language classroom. Lawrence Erlbaum Associates, Inc., Publisher.

Nirwanto, R. (2014). Book review: Questionnaire in second language research. Journal on English as a Foreign Language, 4(2), 91-95.

Nobel, J. P. (2006). Student achievement, behavioral, perceptions, and other factors affecting act scores. ACT Research Report Series.

Sultan, Borland, H., \& Eckersley, B. (2012). English medium of instruction in Indonesian public junior secondary school: Student's language use, attitude/motivation, and foreign language outcomes. ACTA International TESOL Conference. Cairns Australia.

Thirunavukkarsu, K. (2014). Reintroduction of EMI in Sri Langka. International Journal of English Language and Literature Studies.

Toendan, W. (2013). Research Methods. Palangka Raya: University of Palangka Raya.

\section{Author's Brief CV}

Denni Rahmadani was born on Februari $8^{\text {th }}, 1994$. He got his degree of Sarjana Pendidikan Bahasa Inggris from IAIN Palangka Raya in 2016. He is interested in the development of English. So, he is going to continue his study to get a master degree in English Teaching. More Information: Phone: +6281350147721, E-mail: denni22ej@gmail.com, Instagram: denni_rmadani, and Twitter: rahmadani2016. 